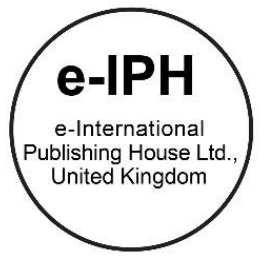

\title{
Reflecting Leadership Effectiveness via Food-hygiene Practices
}

\author{
Mazni Saad ${ }^{1 *}$, Mohamad Faiz Foong Abdullah ${ }^{2}$, Mohammad Halim Jeinie ${ }^{3}$, Rosita Husain 4 \\ ${ }^{1,4}$ Faculty of Business, Universiti Selangor, Jalan Zirkon A 7/A, Seksyen 7, 40000 Shah Alam, Malaysia \\ 2 Faculty of Applied Science, Universiti Teknologi MARA,40450 Shah Alam, Malaysia \\ ${ }^{3}$ Faculty of Health Sciences, Universiti Teknologi MARA,42300 Puncak Alam, Malaysia
}

\begin{abstract}
Good leadership may implicate and reflect positive actions and effective hygiene practices. This study aims to encourage and disseminate the importance of the use of technological tools in detecting risks in Food-hygiene Practices in six governmentcontrolled training centers. The survey and scientific swab method elicited data on leadership effectiveness (LE) prevalent in these organizations, focusing mainly on their impact on human health and the environment. The regression analysis shows that LE significantly affects perception and actual Food-hygiene Practices. The large effect sizes of significance difference for both practices were also detected. Accordingly, recommendations and limitations are highlighted in this study.

(C) 2016. The Authors. Published for AMER ABRA by e-International Publishing House, Ltd., UK. This is an open access article under the CC BY-NC-ND license (http://creativecommons.org/licenses/by-nc-nd/4.0/).

Peer-review under responsibility of AMER (Association of Malaysian Environment-Behaviour Researchers), ABRA (Association of Behavioural Researchers on Asians) and CE-Bs (Centre for Environment-Behaviour Studies), Faculty of Architecture, Planning \& Surveying, Universiti Teknologi MARA, Malaysia.
\end{abstract}

Keywords: Food safety; food-hygiene practice; leadership effectiveness; Malaysia

\section{Introduction}

Food safety is essential for everyday sustainable living. The promotion of a food safety system in the food industry begins with preventative controls and environmental monitoring of programs. These food safety systems are managed by hazard analysis and critical control points (HACCP), which has been applied in a generic food safety management system (FSMS) certification of ISO 22000. Companies in Malaysia show their commitment to FSMS by certifying to ISO 22000, the MS 1514 Good Manufacturing Practice (GMP), and Good Catering Practice (GCP) with the Department of Standards Malaysia (DSM) (Department of Standards Malaysia, 2013).

\footnotetext{
* Corresponding author. Tel.: +6-017-878-7543

E-mail address: maznisaad@unisel.edu.my
}

2398-4287 @ 2016. The Authors. Published for AMER ABRA by e-International Publishing House, Ltd., UK. This is an open access article under the CC BY-NC-ND license (http://creativecommons.org/licenses/by-nc-nd/4.0/).

Peer-review under responsibility of AMER (Association of Malaysian Environment-Behaviour Researchers), ABRA (Association of Behavioural Researchers on Asians) and CE-Bs (Centre for Environment-Behaviour Studies), Faculty of Architecture, Planning \& Surveying, Universiti Teknologi MARA, Malaysia.

DOI: http://dx.doi.org/10.21834/e-bpj.v1i3.371 
Despite putting in place various food safety measures, the current quality of health related to food is still an issue in Malaysia, even within government-controlled foodservice establishments. It can be seen in the continuous food poisoning media reports of public schools, training centers, and hospitals, thus indicating a need to investigate other factors that may contribute to such outbreaks. In line with past research that suggests that a safe and healthy environment could provide the answer to good health, this study postulates that improvements in food safety for better health is also achievable in a healthy environment but one that is implemented and monitored by good and effective leaders.

1.1. Environmental Health Hazards Environmental health hazards can be biological, physical, chemical, biochemical, and psychosocial in nature. A healthy food service environment does not only mean meeting food safety requirements set by the authorities for personal hygiene, kitchen equipment, or premises, but also good cooking and food preparation practices. Obviously, contamination happens to food and water, but unhygienic food preparation and cooking too can be the source of such contamination. Today, leadership effectiveness (LE) is being investigated as having a significant influence on Food-hygiene Practices as good leaders ensure that there is not only a high level of dedication and competitiveness in work performance but also the provision of guidance and discipline for high standard hygiene practices. This study, therefore, focuses on LE as it may have a significant influence on Food-hygiene Practices from two points of view: perception and actual implementation of the hygiene practices. The critical question is whether foodservice establishments are providing safer food for a better public health and environment. In other words, does foodservice's LE significantly affect Food-hygiene Practices?

\section{Literature Review}

\subsection{Food Hygiene Practices}

Poor hygiene practices contribute to food spoilage that can be the cause of disease outbreaks and bacterial infections such as food poisoning. The outbreaks such as Giardia lamblia, Campylobacter jejuni, Cryptosporidium parvum, Escherichia coli 0157:H7, Cyclosporacayetanensis, and Entamoebahistolytica (Combs, Pingault, \& Gibbs, 2012) are closely related to bacteria, viruses, parasites, mold, toxins, contaminants, and allergens. In Malaysia, besides Cholera, Hepatitis A, typhoid and dysentery, food poisoning which is related to water-borne diseases from the year 2000 to 2012 appears to be most critical (Mazni, Toh, \& Mohamed Azam, 2013). The symptoms and effects of food poisoning can be observed on a person within a short period although its long-term consequences are usually associated with kidney failure, chronic arthritis, brain and nerve damage, or even death (U.S. Department of Health \& Human Services, 2013). Coliforms which are mostly present in large numbers are associated with foodborne outbreaks and human illnesses and can be found in fecal wastes (Willis, Elviss, Aird, Fenelon, \& Mclauchlin, 2012).

Kim et al. (2012) added that cleaning methods are a critical hygienic factor in food-safety. As such, the role of public health inspectors is crucial in ensuring public safety specifically in the area of food health and safety. Pham, Jones, Sargeant, Marshall, and Dewey (2010) conducted focus group interviews with 23 public health inspectors to elicit their fears relating to food-safety issues to public health. They raised concerns regarding time-temperature abuse, inadequate hand washing, cross-contamination, lack of food-safety knowledge, and lack of information and resources on specialty foods i.e. foods from different cultures. The findings revealed that thorough and correct food handling practices and behaviors are fundamental to reducing foodborne illnesses.

Food handlers must have adequate knowledge of safe food-handling measures so that food can be prepared safely, hygienically and according to standard food-safety procedures. The efficient implementation of these measures can help avoid food contamination that usually leads to other foodborne diseases. In a study on the appropriate implementation of correct hand-hygiene practices in clinics (Sharma, 2012) revealed that only 55 out of 255 i.e. $21.6 \%$ of respondents among dental professionals had either adequate awareness of hand-hygiene practices or actual practice them at work. It shows that professionals too can lack knowledge and awareness of correct hand-hygiene practices. 
Therefore, food handlers need to learn and practice many simple standardized safety measures such as cleaning hands hygienically and wearing face masks when handling food. They must also wear a head cover; understand product expiry dates as well as other and better food-handling safety measures.

\subsection{Food-contact Surfaces and Cross-contaminations}

Food-contact surfaces (FCS) are used during garnishing, chopping, deboning, and slicing. In a foodservice operation, proper use of FCS is prioritized as a way of controlling the transmission of foodborne pathogens to readyto-eat food (RTE) (Cosby et al., 2008). While contaminated food has a direct effect on human health, contaminated FCS is more critical. It is one of the factors that causes food spoilage and happens when RTE comes into direct contact with FCS. Surfaces of plates, cups, cutting boards, food preparation table, and the like can be recontaminated even after a routine cleaning procedure.

The spread of pathogens on FCS is a risk to public health. A FCS that is contaminated by previous users who do not wash their hands may be touched later by others who wash their hands (Berry et al., 2012). A survey of restroom users in 48 fast food restaurants and coffee shops revealed that restroom designs and appliances spread pathogens via human waste and urinals. Hand hygiene was studied based respondents' hand touch of restroom door entries, toilet stall doors, door locks, and the toilet or urinal flushing mechanism. Others include, sink faucet controls, soap dispensers, hand drying controls, and restroom door exits. Dirty hands have implications for hand hygiene and diseases.

Guyard-Nicodeme et al. (2013) supported Kim et al.'s (2012) findings of cooked chicken slices which were cut on chopping boards when raw. The study identified Campylobacter as the reason for the existence of $\mathrm{C}$. jejuni and C. coli while the cross-contamination transfer isolated almost $30 \%$ of the assays and $90 \%$ of both C. jejuni and C. coli. These results demonstrated the moderate or high contamination ability of static surfaces. In short, critical FCS means a surface that comes into contact with food that ordinarily takes place during the food processing operation, after which the food is subjected to a bactericidal control process.

\subsection{Leadership Effectiveness}

One of the most influential factors that contribute towards organizational success is LE (Schumacher, Grigsby, \& Vesey, 2015). It has received a great deal of attention in many businesses including foodservice (Fulmer, Gibbs, and Goldsmith (2000) and is a crucial area of focus for best-practice organizations. Great talented leaders comprehend what they do and why they do it, significantly inspiring their followers (Hopkins, O'Neil, \& Stoller, 2015) and particularly affecting their personal characteristics, behaviors, as well as perceptions of empowerment (Den Hartog \& Koopman, 2011). Effective leadership is related to certain individual capabilities such as personality traits, a balance of behaviors, a broad set of skills including self-confidence, tolerance for stress and energy, and core competencies (Shipper \& Davy, 2002).

Leadership behavior styles, on the other hand have mostly been emphasized in a group, influences, and goals (Norlida, Hassan, Wahab, \& Hussein, 2014). These authors studied LE among 298 lecturers at three (3) Malaysian research universities and noted differentiated personal traits such as leader based domain creating effective leadership. Their findings showed that transformational leadership from heads of departments is better accepted compared to transactional and Laissez-faire leadership. For example, inspirational motivation addressed by the head of the department is the most appreciated behavior. Lecturers felt they were given assistance and motivation to carry out their responsibilities and work optimistically to achieve greater success in the future.

Another study on LE by Gwen Burns and Martin (2010) showed that gender differences do not have any significant effect on LE. Rather, the follow-up interviews with teachers and principals established that the teachers believed invitational qualities of respect and trust were the most influential leadership qualities. The principals also viewed trust as the predominant influencing factor. 


\subsection{Leadership Effectiveness and Food-hygiene Practices}

This study aims to find the implications of adopting LE on Food-hygiene Practices at six government-controlled foodservice locations as suggested by the Malaysian Ministry of Health. Effective business supervisions need to sustain the affirmative relationship between leaders and subordinates, an association considered necessary for achieving an organization's business objectives. This positive relationship seems to improve a subordinate's personal goal setting (Gatling, Castelli, \& Cole, 2013). According to Den Hartog and Koopman (2011), LE affects the followers' behaviors, including perceptions and empowerment, while Shipper and Davy (2002) found LE related to specific individual capabilities. Hence, LE traits (e.g. self-confidence, hard work, and patience), leaders and subordinates working in proximity such as in kitchen areas of restaurants can influence Food-hygiene Practices among subordinates. It happens when there is a positive relationship between outlets.

In support of a positive relationship between LE and hygiene practices, Stevens, Hemmings, Scott, Lawler, and White (2014) surveyed and interviewed 53 medical and dental staff to unravel clinical leadership style and hand hygiene compliance. Overall, the relationship between leadership style and hand hygiene compliance rates is reasonably negative. The interview findings, however, demonstrated how environmental factors such as role modeling by the leader and the respondents' educational knowledge helped to counter false beliefs about hand hygiene and infection control. Leadership role modeling is effective in improving patient safety performance through increasing hand hygiene compliance.

LE influences subordinate to display good working practices. DuBrin (2007) suggested that indicators of LE include factors such as possessing a good relationship with followers. In a business organization, this positive relationship is significant for the subordinate's health and welfare and imparts a positive effect on the overall business performance. This positive attachment according to Hogg et al. (2005) may unite subordinates into being strong team members although they may each have different values. Some of the values include loyalty, a sense of inclusion, and gratefulness. As these LE qualities are displayed by their leaders, food handlers, also seem to exercise acceptable, standardized and proper Food-hygiene Practices while working in the kitchen.

Kimbrough-Walls (2012) investigated students' perception of important teaching behaviors in the classroom and clinical environment for a nursing and dental hygiene program and found that students' success is dependent on the lecturers' effective instruction. However, they noticed that it is difficult to identify efficient teaching as it is often described differently by students, faculty, and administrators. This leadership by example is also revealed in Lin, Tou, and Yeh (2014) restaurant industry research. They discussed leadership quality-related performance as an effective management indicator. Other effective leadership examples connected to food outlets or foodservice industry are found in studies done by Madera, Dawson, Neal, and Busch (2013), Obonyo, Ayieko, and Kambona (2013), Ryu, Lee, and Kim (2012), and Teng and Chang (2013). The roles of LE that strongly supports and promotes good food-hygiene practices as mentioned in these studies confirm the existence of a positive relationship between LE and Food-hygiene Practices.

The following hypothesis is developed based on the strong evidence found in the above discussion supporting the relationship:

H1: LE has a significant relationship with perceived Food-hygiene Practices

H2: LE has a significant relationship with the actual implementation of Food-hygiene Practices.

\section{Methodology}

A mail survey and a microbial experiment were used to collect data from six foodservice establishments. The food handlers were the captive population as they not only have specific knowledge of food handling activities but also work under controlled conditions where the food quality outcomes are constantly monitored by the Ministry of Health. There is no complete list of all food handlers as the total number of food handlers varies from one foodservice establishment to another. Therefore, based on approximately 10 to 20 food handlers in one center, 90 questionnaire sets were distributed in November 2012. The sampling classification of the survey is judgmental sampling. The questionnaire encompasses personal profile and question items related to the study variables of the current investigation. This study adopted and adapted the 5-items of Reave (2005) to measure LE and 16 -items 
from Bolton, Meally, Blair, McDowell, and Cowan (2008) to measure Food-hygiene Practices of food premises and food handlings. The 6-point Likert scale was adopted to avoid having midpoints as an option. Even-numbered Likert scales lead the response to set at a certain point (Croasmun \& Ostrom, 2011). A statistical analysis of the results was performed using the IBM SPSS Statistics (SPSS) package. A regression analysis, a one-way multivariate analysis of variance (MANOVA), and t-test were mainly used to answer the hypotheses and research questions of this study.

Also, a microbiological investigation of FCS was conducted to estimate a specific viable microorganism (total coliform) present in the kitchen environment and the dining area. The microbial assessment focused on food serving trays and dining table tops. The choice of these samples is consistent with several other reported studies that have included a microbial evaluation of FCS items (Cosby et al., 2008; Mazni, Toh, Mohd Faiz Foong, \& Norazmir, 2013; Schlegelova et al., 2010). Using triplicates of each sample, the microbial assessment of total coliform was 36 ( 3 samples $\times 2$ subjects $\times 1$ parameter $\times 6$ foodservice establishments). Coliforms on FCS are a universally accepted hygiene indicator in studies of microbial contamination due to human or animal activities (de Quadros Rodrigues et al., 2014). The microbial assessment tools used included the Promedia ST-25 swab test kit and the RIDA® Count Coliform count kit. For t-test purposes, both data from the survey and hygiene scorecard were computed to $\log 10$.

\section{Data Analysis and Results}

\subsection{Demographic profile data}

The questionnaire survey was completed within a month. Yielding to the $70 \%$ response rate, 63 sets of usable data from a total of 90 sets of questionnaire were coded and analyzed. This response rate is considered excellent, since responding to mail questionnaires has not been a widely accepted practice in Malaysia (Osman \& Wheeler, 1996). Male food handlers aged between 18 and 30 years old $(40 \%)$ were the majority of the respondents $(60 \%)$. They had less than five years of working experience $(63.5 \%)$.

\subsection{Food serving tray and dining table top}

The cleanliness of food serving trays and dining table tops is another essential factor for consideration in hygienic food handling practices for the final processing stage. The findings from the swab experiments show that total coliforms contaminated almost all of the investigated samples. As shown in Figure 1, dining table tops should be kept clean as it is an open flat surface which is located in the open dining hall and is sometimes used to place clean food serving trays. In the case of the serving trays, contamination could be due to improper cleaning or that secondary contamination has occurred during the drying and storing stage. The presence of total coliform represents environmental contamination and is a risk to consumers. Based on the findings, the hypothesis testing is discussed in the next section. Based on the findings, the hypothesis testing is discussed in the next section.
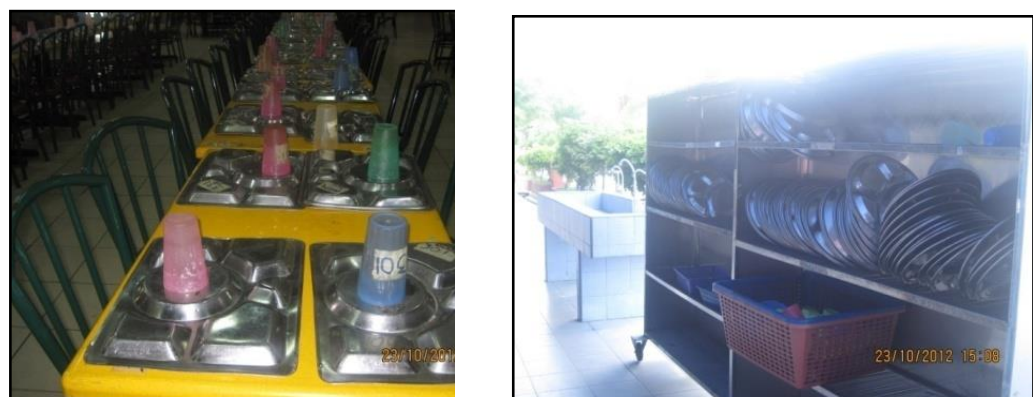

(a) (b)

Fig. 1. (a) Dining table top at Location 5; (b) Food serving tray storage at Location 6. 


\section{Hypothesis Testing}

H1: LE has a positive and significant relationship with perceived Food-hygiene Practices

A simple regression analysis was conducted to test the significant effect of $L E$ on the perceived Food-hygiene Practices. Table 1 indicates that the regression model predicts the perceived Food-hygiene Practices variable as significant with, $p$-value $=0.012$, which is less than 0.05 . The result indicates that statistically the overall regression model significantly predicts the perceived Food-hygiene Practices, although it is in a negative relationship. Thus, the hypothesis $\mathrm{H} 1$ is not supported.

Table 1. ANOVA test for significance Box's Test of Equality Covariance Matrices

\begin{tabular}{llllll}
\hline Model & $\begin{array}{l}\text { Sum of } \\
\text { Square }\end{array}$ & $d f$ & $\begin{array}{l}\text { Mean of } \\
\text { Square }\end{array}$ & F-Value & $p$-value \\
\hline Regression & 2.874 & 1 & 2.874 & 6.772 & 0.012 \\
Residual & 25.885 & 61 & 0.424 & & \\
Total & 28.758 & 62 & & & \\
\hline $\mathrm{R}$ & 0.316 & & & & \\
$\mathrm{R}^{2}$ & 0.100 & & & & \\
\hline
\end{tabular}

From the results in Table 1, we can predict the $R^{2}$ values. The $R$ value represents a simple correlation of 0.316 , which indicates about $31.6 \%$ correlations between LE and LE survey Practices. The $\mathrm{R}^{2}$ value is 0.100 indicating about $10 \%$ variation in the LE survey practices variable. In this case, the $10 \%$ is very small. Table 2 represents the coefficient result of the regression model, the equation of which is:

$$
F H P=4.483-0.282 L E
$$

The coefficient results in Table 2, however, indicate that there is a negative relationship between LE and perceived Food-hygiene Practices.

Table 2. The coefficient

\begin{tabular}{lclll}
\hline Model & $\beta_{i}$ & Std. error & t-test & $p$-value \\
\hline Constant & 4.483 & 0.552 & 8.116 & 0.000 \\
LE & -0.282 & 0.108 & -2.602 & 0.012 \\
\hline
\end{tabular}

\section{H2: LE has positive and significant relationship between the actual implementation of Food-hygiene Practices}

Firstly, a test for normality, linearity, outliers, homogeneity of variance-covariance, and multicollinearity was conducted, and no serious violation was found. A one-way multivariate analysis of variance (MANOVA) was then conducted to test the hypothesis that there would be one or more mean differences between dining table top and food service tray and LE scores. Table 3 shows the statistically significant result of the MANOVA effect with Pillai's Trace $=0.680, F(48,96)=1.765, p<0.010$. Thus, there is a significant effect of LE on dining table top and food serving tray at six different locations. The multivariate effect size was estimated at 0.340 (partial $\eta^{2}=0.340$ ), which implies that $34.0 \%$ of the variance in the canonically derived y Food-Hygiene Practice (dining table top and food service tray) variables were accounted for by LE.

Table 3. Significance multivariate effects.

\begin{tabular}{|c|c|c|c|c|c|c|c|c|}
\hline & Effect & Value & $\mathrm{F}$ & $\begin{array}{l}\text { Hypothesis } \\
\text { df }\end{array}$ & $\begin{array}{l}\text { Error } \\
\mathrm{df}\end{array}$ & Sig. & $\begin{array}{l}\text { Partial Eta } \\
\text { Squared }\end{array}$ & $\begin{array}{l}\text { Observed } \\
\text { Powerb }\end{array}$ \\
\hline \multirow[t]{4}{*}{ Intercept } & Pillai's Trace & .262 & $8.359^{a}$ & 2.000 & 47.000 & .001 & .262 & .877 \\
\hline & Wilks' Lambda & .738 & $8.359^{a}$ & 2.000 & 47.000 & .001 & .262 & .877 \\
\hline & Hotelling's Trace & .356 & $8.359^{a}$ & 2.000 & 47.000 & .001 & .262 & .877 \\
\hline & Roy's Largest Root & .356 & $8.359^{a}$ & 2.000 & 47.000 & .001 & .262 & .877 \\
\hline \multirow[t]{3}{*}{ LE } & Pillai's Trace & .680 & 1.765 & 28.000 & 96.000 & .022 & .340 & .936 \\
\hline & Wilks' Lambda & .404 & $1.927^{a}$ & 28.000 & 94.000 & .010 & .365 & .960 \\
\hline & Hotelling's Trace & 1.271 & 2.088 & 28.000 & 92.000 & .005 & .389 & .975 \\
\hline
\end{tabular}


$\begin{array}{llllllll}\text { Roy's Largest Root } & 1.080 & 3.702^{c} & 14.000 & 48.000 & .000 & .519 & .984\end{array}$

When the results for the Food-hygiene Practice variables were considered separately, the only difference to reach statistical significance when using the Bonferroni-adjusted alpha level 0.015 is the food serving tray, $F(14,48)=$ 3.672, $p$-value $=0.000$. Results depicted as in Table 4 .

Table 4. A significant effect of LE.

\begin{tabular}{llllllll}
\hline Source & Dependent Variable & $\mathrm{df1}$ & $\mathrm{df2}$ & $\mathrm{F}$ & $\mathrm{Sig}$ & $\begin{array}{l}\text { Partial Eta } \\
\text { Squared }\end{array}$ & $\begin{array}{l}\text { Observed } \\
\text { Power }^{b}\end{array}$ \\
\hline Corrected Model & Dining table top & 14 & 48 & .759 & .706 & .181 & .218 \\
& Food serving tray & 14 & 48 & 3.672 & .000 & .517 & .983 \\
\hline
\end{tabular}

Does LE affect Food-hygiene Practices (perceived vs. actual implementation)?

A t-test was conducted for the research question of this study. Table 5 shows the descriptive statistical results of three different variables - perceived Food-hygiene Practices, dining table tops, and food serving trays. It indicates that there is a mean difference between perceived Food-hygiene Practices (Mean $=3.0419, \mathrm{SD}=$ 0.66877 ) and dining table tops (Mean $=1.7155, \mathrm{SD}=0.15465$ ) and also food serving trays (Mean $=1.2876, \mathrm{SD}=$ 0.15192).

Table 5. Descriptive Statistics.

\begin{tabular}{llll}
\hline Variables & $\mathrm{N}$ & Mean & SD \\
\hline Perceived Food-hygiene & 62 & 3.0419 & 0.66877 \\
Dining table tops & 62 & 1.7155 & 0.15465 \\
Food serving trays & 62 & 1.2876 & 0.15192 \\
\hline
\end{tabular}

Then a paired-sample t-test was conducted to evaluate the significant difference between perceived Foodhygiene Practices and dining table tops, and also serving trays. There was a statistically significant difference between perceived Food-hygiene Practices and dining table tops, $t(61)=7.351, p$-value $<0.000$, with the eta square $\left(\eta^{2}\right) 0.4739$ indicating a large effect size (Cohen, 1988). There is also a significant difference between perceived Food-hygiene Practices and food serving trays, $t(61)=11.341, p$-value $<0.000$, with the eta square $\left(\eta^{2}\right)$ 0.6819 , also indicating a large effect size. The detail results are depicted in Table 6.

Table 6. The significance test.

\begin{tabular}{lccccccc}
\hline Research Question & df & $\begin{array}{l}\text { Std.Error } \\
\text { of Mean }\end{array}$ & t-test & $\begin{array}{l}95 \% \text { Confidence Interval } \\
\text { Lower }\end{array}$ & & P-value & $\begin{array}{l}\text { Effect } \\
\text { size }\end{array}$ \\
\hline $\mathrm{H} 3 \mathrm{a}$ & 61 & 0.18044 & 7.351 & 0.96564 & Upper & & \\
\hline $\mathrm{H} 3 \mathrm{~b}$ & 61 & 0.15469 & 11.341 & 1.44504 & 2.68726 & 0.000 & 0.4739 \\
\hline
\end{tabular}

\section{Hypothesis Testing}

This section presents the overall results related to hypotheses, as presented in Table 7. Of the four hypotheses, only the first was not supported.

Table 7. Summary of hypothesis testing

\begin{tabular}{llc}
\hline $\mathrm{H} 1$ & There is a positive and significance difference between LE and perceived Food-hygiene Practices & Not Supported \\
\hline $\mathrm{H} 2$ & There is a positive and significance difference between LE and actual implementation of Food-hygiene Practices & Supported \\
\hline
\end{tabular}




\section{Discussion and implications of the study}

The above findings highlight the importance of LE in predicting two outcomes of Food-hygiene Practices in foodservice establishments within the control of the Ministry of Health. For the first hypothesis - LE has a significant effect on perceived Food-hygiene Practices. The survey results show that food handlers have a poor perception of their leaders' management of food-hygiene practices. It is similar to that found by Stevens et al. (2014) and Sharma (2012), where leadership also has a negative impact on hygiene practices and even suggested that factors such as the environment, education, role modeling, and knowledge may be more important determinants. Leaders may not necessarily be professional practitioners, but can still be considered role models because of other management qualities or personality traits. The second analysis that uses a hygiene scorecard (swab analysis) proves that LE has significant effects on the actual implementation of food handling practices by their organizational leaders. This outcome is consistent with Lin et al. (2014) and Kimbrough-Walls (2012). Kimbrough-Walls (2012) although said that it is hard to measure efficient leadership as most of the time the concept of leadership is interpreted differently by the staff.

From the management perspective, the results from hypothesis one may have a different implication and interpretation. In the six government-controlled foodservice centers, the Ministry of Health plays an important role in monitoring foodservice, while each different foodservice owner prepares the premises and runs the businesses. The food handlers of each center receive information on good Food-hygiene Practices directly from the Ministry of Health and may perceive the ministry as good leaders. The ministry's involvement is actually part of the management's effort at inculcating good hygiene practices. The findings lend support to the view that perception and actual implementation of Food-hygiene Practices reflect the management of these government-controlled centers and their LE. A strong leadership and LE that promote positive foodservice qualities further enhance the overall management skills of employees, i.e. employees' willingness to perform good Food-hygiene Practices at their food service outlets. Their ability to maintain the cleanliness and hygienic environment of their outlets is critical in the food service industry.

From the practical perspective, the use of the technological tool of swab test on FCS provides significant implications on the effective and efficient FCS after the cleaning process as suggested by Mazni, Toh, Mohd Faiz Foong, et al. (2013). The result from the microbial analysis reflects the actual contamination status of the Foodhygiene Practices. Food serving trays and dining table top are important samples because if the food does not go through the heating process before being served to consumers, direct contact with a contaminated FCS can easily transpire a bacterial infection of the food. Due to the effectiveness of their leaders, the equipment, utensils, and the areas where the food is processed or prepared were given full attention during the cleaning process. The hygiene scorecard should be utilized as a commercial tool rather than limiting its use for laboratory purposes only.

\section{Limitations and future research}

One limitation of this study is that the investigation could only conduct at six critical foodservices recommended by the Ministry of Health. Thus, the sampling size is the first concern. Only 63 usable data were computed and analyzed to show the food handlers' perception of Food-hygiene Practices. Although the data were small, it did represent the population at each foodservice establishment. Thus, to meet the statistical expectations of ANOVA, Pillai's trace test was used. Future studies may replicate this for a longitudinal study that could monitor $L E$ and its impact on Food-hygiene Practices among the six foodservice establishments.

The second limitation is the experimental sampling that used the hygiene score card to investigate the cleanliness for food serving trays and dining table tops. These two types of FCS represent the final process of foodservice. Future studies may investigate the first and intermediate processes such as cutting boards, and the middle process such as cutting boards, wiping towels, spatula, and pots and pans to reflect the whole food premise. Furthermore, a longitudinal study could elicit the pattern of actual food-hygiene practices.

Another interesting outcome of the findings could be the exploration of the positive and significant relationship between the perceived and actual implementation of Food-hygiene Practices - to find out if the food handlers' 
perception is accounted for in the actual implementation of Food-hygiene Practices in foodservice. Besides, in replicating LE's effect on perceived food-hygiene practices, further studies could introduce other factors such as attitude or spiritual intelligence of the food handlers as the mediator or moderator variable.

\section{Conclusion}

The LE in this study seems to have a significant impact as well as reflect positive actions and effective hygiene practices in the actual implementation of Food-hygiene Practices. Food handlers might perceive that they are practicing good work due to the interference of regular monitoring activities from the Ministry of Health. It is not something new because, in reality, the involvement of the ministry is part of the initiative of the food establishments' management because these foodservices are under the government-controlled. Such contradicted findings between perception and actual implementations might create different reflections of the practice although both are equally significant. The survey and scientific swab methods do reflect their impact on human health and the environment. In fact, the large and significant effect sizes statistically were evident. Nevertheless, this study would like to emphasize that the use of the technological tool i.e. the hygiene scorecard (i.e. via swab assessment) is valuable as it reflects the foodservice establishment's effective and efficient control and monitoring of environmental hazards in reaching a hygienic environment.

The current study leaves some questions that require further explanation. If the leaders were effective for the hygiene practices, could it be that other factors are perhaps causing the recurrence of food-related outbreaks in the government-controlled centers? This calls for the consideration of a new study of food hygiene practices in the future.

\section{Acknowledgements}

This research was partially funded by Universiti Selangor (UNISEL) through the Faculty of Business in Shah Alam, Selangor. The main author gratefully thanks the UNISEL for awarding her permission to participate in the current conference. The author also thanks the Quality Division Department of Public Health Ministry of Health Malaysia for their cooperation to conduct this study.

\section{References}

Bolton, D. J., Meally, A., Blair, I. S., McDowell, D. A., \& Cowan, C. (2008). Food safety knowledge of head chefs and catering managers in Ireland. Food Control, 19, 291-300.

Cohen, J. (1988). Statistical power analysis for the behavioral sciences. Mahwah, NJ: Lawrence Erlbaum.

Combs, B., Pingault, N., \& Gibbs, R. (2012). Foodborne disease surveillance and outbreak investigations in Western Australia 2012. Perth, Australia.

Cosby, C. M., Costello, C. A., Morris, W. C., Haughton, B., Devereaux, M. J., Harte, F., \& Davidson, P. M. (2008). Microbiological analysis of food contact surfaces in child care centers. Applied and Environmental Microbiology, 74(22), 6918-6922.

Croasmun, J. T., \& Ostrom, L. (2011). Using Likert-type scales in the social sciences. Journal of Adult Education, 40(1), 19-22.

de Quadros Rodrigues, R., Loiko, M. R., de Paula, C. M. D., Hessel, C. T., Jacxsens, L., Uyttendaele, M., . . . Tondo, E. C. (2014). Microbiological contamination linked to implementation of good agricultural practices in the production of organic lettuce in Southern Brazil. Food Control, 42, 152-164.

Den Hartog, D., \& Koopman, P. (2011). Leadership in Organiations (Vol. 2).

Department of Standards Malaysia, S. f. t. A. o. C. B. (2013). ACB-Good Manufacturing Practice for Food (GMP). In S. Malaysia (Ed.), Standards Malaysia Requirements for the Accreditation of Bodies Operating Certification of Good Manufacturing Practice for Food to MS 1514 (pp. 15). 
DuBrin, A. J. (2007). Leadership research: Findings, practice, and skills (5th. ed.). Boston, MA: Houghton Mifflin Company.

Fulmer, R. M., Gibbs, P. A., \& Goldsmith, M. (2000). Developing leaders: how winning companies keep on winning. Sloan Management Review(Fall), 49-59.

Gatling, A. R., Castelli, P. A., \& Cole, M. L. (2013). Authentic leadership: the role of self-awareness in promoting coaching effectiveness. AsiaPacific Journal of Management, 9(4), 337-347.

Guyard-Nicodeme, M., Tresse, O., Houard, E., Jugiau, F., Courtillon, C., El Manaa, K., . . . Chemaly, M. (2013). Characterization of Campylobacter spp. transferred from naturally contaminated chicken legs to cooked chicken slices via a cutting board. International Journal of Food Microbiology, 164(1), 7-14.

Gwen Burns, E. D., \& Martin, B. N. (2010). Examination of the effectiveness of male and female educational leaders who made use of the invitational leadership style of leadership Journal of Invitational Theory and Practice, 16(27).

Hogg, M. A., Martin, R., Epitropaki, O., Mankad, A., Svensson, A., \& Weeden, K. (2005). Effective leadership in salient group: revisiting leadermember exchange theory from the perspective of the social identity theory of leadership Personality and Social Psychology Bulletin, 13(7), 9911004.

Hopkins, M., O'Neil, D. A., \& Stoller, J. K. (2015). Distinguishing competencies of effective physicial leaders. Journal of Management Development, 34(5), 566-584.

Kim, S.-Y., Li, T., Heo, J.-Y., Bae, Y.-M., Hwang, I.-K., Lee, S.-Y., \& Moon, B. (2012). Efficacies of cleaning methods for decontaminating vibrio parahaemolyticus on the surfaces of cutting boards cross-contaminated from grated fish fillet. Journal of food Safety, 32(4), 459-466.

Kimbrough-Walls, V. J. (2012). Students' Perception of Important Teaching Behaviors in Classroom and Clinical Environments of a Community College Nursing and Dental Hygiene Education Program. (3511838 Ph.D.), University of Nevada, Reno, Ann Arbor. Retrieved from http://search.proquest.com.ezaccess.library.uitm.edu.my/docview/1024141591?accountid=42518 ProQuest Dissertations \& Theses Global database.

Lin, W.-S., Tou, J.-C., \& Yeh, M.-Y. (2014). The effective performance measures for store managers on restaurant chain growth. Tourism and Hospitality Research, 14(3), 131-142.

Madera, J. M., Dawson, M., Neal, J. A., \& Busch, K. (2013). Breaking a communication barrier: the effect of visual aids in food preparation on job attitudes and performance. Journal of Hospitality \& Tourism Research, 37(2), 262-280.

Mazni, S., Toh, P. S., \& Mohamed Azam, M. A. (2013). Hygiene practices of food handlers at Malaysian government institutions training centers. Procedia - Social and Behavioral Sciences, 85, 118-127.

Mazni, S., Toh, P. S., Mohd Faiz Foong, A., \& Norazmir, M. N. (2013). Use of rapid microbial kits for regular monitoring of food-contact surfaces towards hygiene practices. Procedia - Social and Behavioral Sciences, 105, 273-283.

Norlida, K., Hassan, Z. f., Wahab, R. A., \& Hussein, R. M. (2014). Principles of Management. Malaysia: Oxford Fajar.

Obonyo, G. O., Ayieko, M. A., \& Kambona, O. O. (2013). An importance-performance analysis of food service attributes in gastro-tourism development in Western Tourist Circuit, Kenya. Tourism and Hospitality Research, 12(4), 188-200.

Pham, M. T., Jones, A. Q., Sargeant, J. M., Marshall, B. J., \& Dewey, C. E. (2010). A qualitative exploration of the perceptions and information needs of public health inspectors responsible for food safety. BMC Public Health, 10(345), 1-9.

Reave, L. (2005). Spiritual values and practices related to leadership effectiveness. The Leadership Quarterly, 16(5), 655-687.

Ryu, K., Lee, H., \& Kim, W. G. (2012). The influence of the quality of the physical environment, food, and service on restaurant image, customer perceived value, customer satisfaction, and behavioral intentions. International Journal of Contemporary Hospitality Management, 24(2), 200223.

Schlegelova, J., Babak, V., Holasova, M., Konstantinova, L., Necidova, L., Sisak, F., . . Jaglic, Z. (2010). Microbial contamination after sanitation of food contact surfaces in dairy and meat processing plants. Czech J. Food Sci., 28(5), 450-461.

Schumacher, G., Grigsby, B., \& Vesey, W. (2015). Determining effective teaching behaviors through the hiring process. International Journal of Educational Management, 29(1), 139-155.

Sharma, S. (2012). Hand Hygiene Practice-Perception and Performance. A Survey among Dental Teaching Faculty from a Metropolitan City- 
Chennai, India.

Shipper, F., \& Davy, J. (2002). A model and investigation of managerial skills, employees' attitudes, and managerial performance. Leadership Quarterly, 13, 95-120.

Stevens, S. C., Hemmings, L., Scott, C., Lawler, A., \& White, C. (2014). Clinical leadership style and hand hygiene compliance. Leadership in Health Services, 27(1), 20-30. doi: http://dx.doi.org/10.1108/LHS-09-2012-0029

Teng, C.-C., \& Chang, J.-H. (2013). Mechanism of customer value in restaurant consumption: Employee hospitality and entertainment cues as boundary conditions. International Journal of Hospitality Management, 32(0), 169-178. doi: http://dx.doi.org/10.1016/j.jijhm.2012.05.008

U.S. Department of Health \& Human Services. (2013). Your Gateway to Federal Food Safety Information. FoodSafety.gov. Retrieved 28 April, 2013, from www..foodsafety.govpoisoning/effects/index.html

Willis, C., Elviss, N., Aird, H., Fenelon, D., \& Mclauchlin, J. (2012). Evaluation of hygiene practices in catering premises at large-scale events in the UK: Identifying risks for the Olympics 2012. Public Health, 126, 646-6546. 